\title{
БОРИС АЛЕКСАНДРОВИЧ КАЛОЕВ О ЯЗЫКАХ И ЯЗЫКОВЕДАХ
}

\section{Е.Б. Бесолова}

Борис Александрович Калоев известен ученому миру как неутомимый исследователь-этнолог, которому принадлежат капитальные труды, ставшие прочной опорой для современного кавказоведения. Его, стоящего у истоков становления и развития кавказоведческой науки, отличали широта научного диапазона, пытливость, доброжелательность, индивидуальность и глубокое понимание значения комплексного изучения народов Кавказа. Собранный профессором Калоевым полевой материал более чем за полувековой период, выявленные архивные и музейные данные, ставшие основой фундаментальных монографий, очерков и множества статей, не могут не внушать доверие и уважение к великому труженику науки этнографии. Но поистине уникальны, рассыпанные в трудах Калоева, сведения об осетинском языке и языковедах, с которыми ученого не раз сводила судьба. Теплота и взвешенность отзывов, тонкий юмор и острая наблюдательность в этих воспоминаниях и оиенках привлекают читателя, создают атмосферу дружеского общения. Добрая дружба и многолетнее близкое общение между Калоевым и Абаевым имела жизненную основу: оба - не кабинетные ученые, в большинстве их работ - полевой материал, добытый на местах проживания кавказских народов; оба заботились о сохранении родного языка и первостепенной задачей считали постепенный переход к своему историческому самоназванию “аланы”. Бесиенен дневник, данный в качестве приложения к книге Бориса Александровича "Василий Иванович Абаев и вопросы этнографии в его трудах», изданной $\kappa$ столетию со дня рождения выдающегося учёного. Среди всех работ о венгерских аланах особняком стоит книга Бориса Александровича, в которой внимание читателя привлекает подраздел “"Яский словник" как этнографический источник по аланам-осетинам», в котором около 40 ясских слов на татинском шрифте. Словник XV века, сопровождаемый тмзательным анализом акад. Ю. Немета, публикуется на венгерском языке, затем и на немецком; с последнего переведён В.И. Абаевым на русский язык с обширными комментариями.

Ключевые слова: осетиноведь, истоки осетинского языка, словари, русские учёнье, фольклор, нартоведение.

Boris Alexandrovich Kaloyev is known to the scientific world as a tireless explorer-ethnologist, whose capital researches have become a groundwork for modern Caucasian studies. He conducted pioneer research in the field of Caucasian science and was distinguished by the breadth of his scientific interests, inquisitiveness, benevolence, individuality and deep understanding of the importance of a comprehensive study of the peoples of the Caucasus. The field material gathered by Professor Kaloyev for more than half a century, the identified archival and museum data, which became the basis of fundamental monographs, essays and many articles, cannot but give credence in and respect for the great worker of ethnographic science. But truly unique is the information scattered in Kaloyev's works about the Ossetian language and linguists, with whom the scientist cooperated. The warmth and balance of his reviews, subtle humor and keen observation in these memories and assessments attract readers; create atmosphere of friendly communication. Kind friendship and long-term close communication between Kaloyev and Abaev had common ground: both of them were not armchair scientists, most of their works are based on the field material obtained in the places of Caucasian peoples residence; both of them took care to preserve their native language and considered a gradual transition to their historical self-name "Alans" to be their primary goal. The diary given as an appendix to Boris Alexandrovich's book "Vasily Ivanovich Abaev and questions of ethnography in his works", published on the centenary of the birth of an outstanding scientist, is invaluable. The book of Boris Alexandrovich on Hungarian Alans occupies prominent place among other works on this 
subject. In this book the attention of the reader is attracted by the subsection "The Yass Dictionary" as an ethnographic source for the Alan-Ossetes"”, in which there were about 40 Yas words in Latin script. The XV-th century glossary, supplied by a thorough analysis of Acad. J. Nemeth, was published first in Hungarian, then in German; and then from the latter was translated by V.I. Abaev into Russian with extensive comments.

Keywords: Ossetians, the sources of the Ossetian language, dictionaries, Russian scientists, folklore, nartology.

На юбилее В.И. Абаева акад. О.Н. Трубачев как-то заметил, что Василий Иванович постоянно учил нас «примером своей жизни не отрывать деятельность ученого от всей его нравственной тичности» $[1,4]$.

К тем ученым, деятельность которых никак нельзя оторвать от их «нравственной личности», относился и патриарх этнологии, доктор исторических наук, заслуженный деятель науки Осетии, профессор Борис Александрович Калоев. Б.А. Калоев - один из авторов академических изданий «Мифы народов мира», «Народы России. Энциклопедия», «Страны и народы»; автор 20-ти крупнейших монографий по этногенезу, этнической истории, материальной и духовной культуре осетин, по различным проблемам кавказской этнологии; его изыскания «Осетины: историко-этнографическое исследование», выдержав три издания, завоевали право на настольную книгу кавказоведов.

Поражали всех уважение и отеческая любовь к молодым ученым из самых разных регионов России и зарубежья, которых проф. Калоев консультировал; а также внимательное, доброжелательное и бережное отношение к аспирантам и соискателям, у которых он был научным руководителем.

На протяжении многих лет ученый-этнолог вел полевые исследования в различных районах Кавказа, собирая уникальный этнографический материал.

В «Записках кавказоведа», в разделе о своем жизненном и творческом пути, Борис Александрович знакомит чита- теля с этнонимом «Кало», означающим по-грузински «девушка», «женщина», давшим имя родоначальнику Калоевых. «Едва ли не единственный в осетинской действительности факт, когда род ведет свое начало от женщины!», - восклицает Борис Александрович. Констатация этой реальности вызывает у читателя улыбку $[2,10]$. Но далее сообщает, что, по рассказам отца, их « родоначальником считается Тапсыхъо (имя, судя по суффиксу -хъо, явно кабардинское)» $[2,12]$.

Борис Александрович, неторопливый, осторожный и наблюдательный, был прекрасным психологом, больше слушал, чем говорил, а слушая собеседника, ненавязчиво направлял его мысль и беседу в нужное ему русло.

Интересны характеристики и оценки, данные Калоевым «тонким знатокам осетинского языка, фольклора и быта».

В отношении Цоцко Амбалова: «Цоцко Амбалов был уникальной личностью: был хорошо знаком с М.М. Ковалевским, слушал лекции ученого в 1900 году в Париже, а также в Русской высшей школе. Прекрасно владел немецким языком, переводил на осетинский язык произведения немецких классиков [2, 149]. Любимец осетинской интеллигенции, известный просветитель, много лет отдал подготовке посмертного академического издания «Осетинско-русско-немецкого словаря» В.Ф. Миллера, большой друг В.И. Абаева. По словам Абаева, Цоцко Амбалов был приглашен Академией наук в Ленинград, преподавал там осетинский язык студентам восточного факультета Университета; «прекрасный знаток осе- 
тинского языка, всегда находился в окружении студентов, вместе с ними обедал в студенческой столовой. Брал у него уроки осетинского языка и этнолог Леонид Иванович Лавров. Вернувшись в Осетию, был репрессирован в 1937 году по доносу, в тюрьме не выдержав, покончил с собой, разбив голову об стенку» $[2,37]$.

Высоко ценил Калоев первых профессоров-осетин - Бориса Алборова и Губади Дзагурова. Познакомился с ними в конце 50-х годов прошлого века, после их возвращения из ссылки, куда ученые были сосланы по ложному доносу. Особенно почитал Бориса Андреевича Алборова: «как человека и ученого, внесшего значительный вклад в осетиноведение и организацию народного просвещения. Его отличала доброта и мужество, не дававших ему склонять голову перед прислужниками любого режима» $[2,35]$.

Очень тепло отзывался Калоев о выдающихся русских языковедах, стоявших у истоков осетиноведения, - А. Шегрене, В.Ф. Миллере; а также о местной интеллигенции, получившей бесплатное образование в вузах России; о профессоре Б.Д. Скитском, воспитавшем несколько поколений учителей горцев, чьей второй родиной стала Осетия [2, 35]; о казакекавказце из Сунжи, профессоре Л.П. Сeменове, авторе прекрасных работ по литературоведению, фольклору и нартоведению: монографии о Коста Хетагурове, о пребывании А.С. Пушкина и М.Ю. Лермонтова на Кавказе и др. [2, 36]

Впечатляет монография о Миллере, при работе над которой Калоев, по совету Георгия Александровича Кокиева, обратился за помощью к сыну ученого, профессору Борису Всеволодовичу Миллеру, известному иранисту и кавказоведу, старшему научному сотруднику Института мышления им. Н.Я. Марра (ныне Институт языкознания АН). Сын передал Калоеву большую папку со словами: «Здесь найдете ценный материал для своего реферата, и это будет лучшим памятником для отца, если опубликуете их» $[2,72]$. Написанию книги способствовал также ВАбаев, которому Борис Александрович передал впоследствии рукопись с приложением переданных ему писем для редактирования, и она была издана в Орджоникидзе в 1963 году.

Личность Миллера, профессора Московского университета, директора Лазаревского института восточных языков (умершего в 1913 г.), рассмотрена в исследовании с уважением к его человеческим и научным заслугам.

Из книги узнаем, что. Миллер владел двумя диалектами осетинского языка, и это помогало ученому в составлении трехтомного разноязычного словаря; десятки лет изучал осетин и Осетию, исходив ее вдоль и поперек, что вылилось в фундаментальный труд «Осетинские этюды» и во множество работ, посвященных осетинам и другим ираноязычным народам Кавказа; сжился с осетинами, подготовил немало исследователей-энтузиастов как для помощи ему, так и для сбора языкового и фольклорного материала.

Решением администрации Владикавказа от 16 января 1997 г. по письменному настоянию двух видных ученых - В.И. Абаева и Б.А. Калоева - улица Советов была переименована в улицу имени Всеволода Федоровича Миллера. Осетины воздали должное ученому-кавказоведу из Российской академии наук за его огромный вклад в становление и развитие осетиноведения и осетинской культуры.

Поражает читателя и разносторонняя информативность сведений о родном языке, имеющаяся в работах Калоева. К примеру, что первый школьный букварь на дигорском диалекте осетинского языка на основе русской (шегреневской) графики составил Цара Гарданов, талантливый учитель церковно-приходской школы в Дигорском ущелье, дед Валентина Кон- 
стантиновича (Батраза Амурхановича) Гарданова. Сын Цара, Муха (Константин, он же Амурхан), отец Валентина Константиновича, будучи еще студентом, был активным помощником Миллера по сбору лексического материала для трехтомного словаря, а также устного народного творчества осетин-дигорцев; что и Михаил Гарданов, народный учитель, проживший более ста лет в полном здравии, был неутомимым собирателем фольклора еще до революции и автором-составителем букваря для школы на дигорском наречии [2, 153].

В селе Галиат на свадьбе ученый был удивлен тем, что соседи по столу разговаривали и произносили тосты каждый на своем наречии. Образовавшееся в Уаллагкоме смешанное население из носителей двух диалектов осетинского языка - коренных дигорцев и пришлых из соседнего Алагирского ущелья иронцев отличалось, по его мнению, тем, что «обе эти этнические группы сосуществовали самостоятельно, поскольку были равными по численности. Дигорцы не могли передать иронцам своего наречия..., кроме того, в результате такого общения дигорское наречие утратило в этих местах многие свои черты» $[2,157]$.

Но наиболее полезен для лингвиста и фольклориста материал Б. А. Калоева о моздокских осетинах, проживающих на хуторах Веселом и Новогеоргиевском, называющих себя иржтт, иъбайтсе (колодцы); а также в хуторах Черноярская и Ново-Осетиновская (в 25 км от Моздока) - осетины-ерашти, дзерашти, по официальным документам - чернояриа$\mathcal{M U}$, состоящими почти исключительно из осетин-дигорцев.

Калоев ознакомился с документами в центральных и местных архивах о возникновении этих поселений, а также с двумя журнальными статьями: краеведа Сосиева - о чернояриах; профессора Б.А. Алборова - об ирюттме»- избайтю $[2,82]$.
Для ученого стало открытием, что осетины-цъайтюе почти поголовно знают ногайский язык и фольклор, и это он объясняет соседством и контактами с ногайцами. Его удивило также исполнение осетинами ногайских песен, ногайских сказок и преданий $[2,83]$.

С осетинами-иъбайтю, говорившими на иронском диалекте осетинского языка, Калоев общался не на русском, как это было у осетин-ерашти, а на родном языке. Он пишет, что эта группа многоязычна, причем старшее поколение, кроме родного и русского языков, хорошо знает ногайский, кабардинский, отчасти и калмыцкий языки; сожалеет также о том, что превосходное знание здешними осетинами ногайского языка и фольклора, к сожалению, сопровождалось утерей ими многого из своего традиционного устного творчества. К примеру, на осетинской свадьбе пели осетины в основном ногайские песни, иногда - русские $[2,96]$.

По мнению Калоева, традиционные мужские и женские имена осетинерашти имеют много аналогий с древнеиранскими, что, по его мнению, представляет большой научный интерес и нуждается в основательной разработке $[2,92]$.

Не могут оставить человека равнодушным страницы в «Дневнике кавказоведа», посвященные Валентину Константиновичу (Батразу Амурхановичу) Гарданову. С горечью пишет Борис Александрович о том, что незнание родного, осетинского, языка мешало ученому с большой эрудицией, обширными знаниями и талантом оратора приезжать в Осетию (не более 3-4 раз), где у него было много родственников. Вырос Гарданов в семье, где говорили только по-русски, потому что отец был осетин, а мать - еврейкой. С огорчением пишет Калоев о том, что незнание осетинского языка является причиной того, что «этот крупный историк-кавказовед не оставил о 
своем народе ни одной строчки, посвятив себя изучению адыгских народов» [2, 155]. Подтверждается тезис, выдвинутый Абаевым: «Осетин, потерявший родной язык, или не владеюший им, перестает быть осетином».

В монографии «Осетины: Историко-этнографическое исследование» Калоев пишет, что язык осетин принадлежит к иранской ветви индоевропейской семьи, точнее - к северо-восточной группе иранских языков, к которой относят хорезмийский, согдийский и сакский языки, а также языки древних скифов и сарматов. Определенное влияние на осетинский язык, на его лексику и систему согласных звуков оказали в процессе многовекового общения кавказские языки. Значительно обогатило осетинский язык, особенно его словарный состав, влияние русского языка. современный осетинский язык делится на два основных диалекта: иронский (восточный) и дигорский (западный). По определению лингвистов, дигорский диалект более архаичен. В основу литературного языка положен иронский диалект, на котором говорит подавляющее большинство осетин $[3,53]$.

Некоторые ученые, в том числе и Миллер, ошибочно признавали, считает Калоев, наличие у осетин и туальского диалекта, на котором, по их мнению, говорят осетины, живущие за Главным хребтом и в Туалгоме (в верховьях Ардона). Заслугой Абаева, пишет Борис Александрович, является выявление того, что никакого туальского диалекта в Юго-Осетии не существует; он также установил наличие трех говоров: туальского, джавского или кударского, и ксанского, примыкающих к иронскому диалекту, и дал глубокую характеристику основным диалектам осетинского языка, а также определил время появления их носителей на Центральном Кавказе [3, 298].

По Абаеву, в ряде явлений фонетики и морфологии дигорский и иронский диалекты могут быть рассматриваемы как два последовательных этапа одного и того же языка... несомненно, что дигорский сохранил значительное число иранских слов, отсутствующих в иронском..., с другой стороны, можно привести ряд случаев противоположного порядка [3, 299].

По определению Абаева, осетинский язык характеризуется участием в его становлении древнескифосарматского и местных языков. Ученый считал, что «... реальную историю осетинского языка можно строить только из предпосылки, что окончательное формирование этого языка совершалось не где-то в Средней Азии или Придонье, а здесь, на Кавказе, в процессе теснейшего взаимодействия и скрещения двух основных языковых стихий: пришлой иранской и местной яфетической в ее нескольких разновидностях. В пользу этого красноречиво говорят и этнические названия осетинских племен: Ир, Дигор, Туал, которые не имеют ничего общего с иранским миром и представляют старые местные наименования» $[3,300]$.

Калоев приводит предположение Миллера относительно того, что у ираноязычных предков осетин в древности существовал единый разговорный язык, позже распавшийся на две ветви, между которыми вследствие условий местных и исторических, не было тесных сношений. У алан-осетин появились два наречия: западное - дигорское и восточное - иронское; у дигорских предков, оказавшихся изолированными в горах Западного Кавказа после их прихода с юга России, развитие языка происходило медленнее. Восточная ветвь, предки нынешних иронов, по словам Миллера, легче добывали средства пропитания, имели широкие связи с другими народами и вообще развивались быстрее носителей дигорского наречия. Однако вопрос об образовании двух диалектов осетинского языка, их 
появлении на территории Западного и Центрального Кавказа остается пока нерешенным. Но, по мнению Бориса Александровича, приведенные высказывания ученого по данному вопросу являются лишь гипотезой.

Калоев акцентирует наше внимание на утверждении Миллера о том, что, хотя в осетинском языке значительное количество древнеиранских слов, в нем также много заимствований из языков соседних кавказских народов: грузинского, кабардинского [3, 300].

К монографии «Венгерские аланы (ясы): Историко-этнографический очерк» [6, 268-286] Калоев приложением дает «Из исследования Ю. Немета. “Список слов на языке ясов, венгерских алан" (Орджоникидзе, 1960; перевод с немецкого В.И. Абаева)». Это - самое ранее свидетельство алано-венгерских лексических и культурных контактов, выявленных в начале XX в. известным венгерским ученым Д. Мункачи. Слова восприняты не только у алан, но и отчасти у скифо-сарматов в период пребывания мадьяр на своей прародине.

Ясский «Словник» является единственным в своем роде памятником аланского языка, дающим яркое представление об ясском языке и самобытной культуре ясов. Лингвисты уже определили его значение для истории аланского и осетинского языков; на основании сравнительного анализа выявили, что носителями лексики памятника являлись северокавказские аланы, прямые предки современных осетин. Но словник считается также важнейшим источником для характеристики некоторых этнографических особенностей алан-осетин.

Калоев пишет, что ясы проявляют большой интерес к языку своих предков и ко всему, что относится к истории Осетии; что компактное расселение ясов, значительная обособленность в прошлом от окружающего населения, отсутствие в Венгрии до первой половины XIX века единого государственного языка позволили ясам сохранить родной язык до XVII в. [6, 80]. В настоящее время ясы говорят по-венгерски, память о своем языке не сохранили.

Однако из ясского венгерский язык позаимствовал много древнеиранских (осетинских) слов, бытующих ныне широко в нем; ср.: хид - “мост", керm <кюрт, ассонь < осет. схсин, жфбсин "госпожа, хозяйка" и др.

Словник начинается со слов приветствия, затем идут термины, обозначающие названия домашних животных и птиц, хлебных злаков и кормов, пищи и напитков, домашней утвари.

Вызывает удивление тот факт, что почти все ясские слова из Словника соответствовали осетинским, были близки дигорскому диалекту осетинского языка, подавляющее большинство слов которого восходит к иранским корням. Кроме того, встречались и заимствования из тюркского, русского, кавказского субстратного [6, 103].

Калоев в связи с находкой «Ясского Словника» подробно останавливается на статье В.И. Абаева «К алано-венгерским лексическим связям», в которой анализируется 131 слово венгерского, тюркского и кавказского происхождения $[6,83]$. По мнению ученого, постоянные и длительные контакты венгров с ираноязычными племенами послужили важнейшим фактором в формировании их культуры и сложении словарного фонда языка, в котором выявляются элементы материальной, духовной культуры и верований ираноязычных. «Важным подтверждающим фактором может служить то, что значительное число осетинских имен восходит к венгерскому языку. Таковыми считаются Белаон, Алдатов, Гутиевы, Газдановы, Тавасиевы, Дулаевы.

Этногенетически интерес приобретает происхождение фамилии Дулаевых, по 
определению Абаева, идущей от имени князя аланского Дула. По легенде, князь имел двух дочерей, на которых женились два брата, Хунор и Могор. Отсюда и ведет свое происхождение венгерский народ» $[6,83]$.

«Словник» трактуется как ценный языковой и этнографический источник, дающий возможность характеризовать главные отрасли хозяйства алан-осетин, предметы материальной культуры до монгольского нашествия. Почти все встречающиеся в нем названия хлебных злаков, животных, предметов быта и т.д. восходят к иранскому. Тюркские и древнекавказские составляют в нем всего несколько названий $[6,113]$.

Пожалуй, наиболее впечатляют страницы, посвященные выдающемуся ученому - В.И. Абаеву, с которым Бориса Александровича связывала долгая мужская дружба.

В книге «Василий Иванович Абаев и вопросы этнографии» Калоева нас привлек биографический очерк об ученом-универсале, «не кабинетном ученом, активном собирателе полевого материала о кавказских народах на местах их проживания», авторе более 500 публикаций и пятитомного «Историко-этимологического словаря осетинского языка», не имеющего аналога в отечественной науке, - Василии Ивановиче Абаеве. По признанию Бориса Александровича, монография основывается на информации, полученной им непосредственно от Абаева, и является итогом многолетнего близкого общения с ним, в ней использованы также данные из трудов великого ученого.

Автор в работе останавливается на уникальном соединении простоты и величественности в Василии Ивановиче Абаеве, на гармонии его личных качеств, способности никогда не суетиться и не терять достоинства в любых ситуациях, учиться умению быть счастливым, благожелательным и преданным делу, не- смотря на долгую и трудную жизнь, на болезнь и происки недоброжелателей. К примеру, Абаев не сломался, лишившись Государственной (Сталинской) премии за выдающий труд «Нартовский эпос» после разгромной рецензии Валентина Константиновича Гарданова, вышедшей накануне присуждения, в 1945 г. Впоследствии Гарданов признался в том, что сделал это по настоянию недруга Абаева - С.П. Толстова, автора книги «Древний Хорезм». Пытаясь загладить свою вину, Гарданов на 70-летии юбиляра в Институте языкознания АН СССР приветствовал Абаева и дал блестящую оценку его трудам.

Но надо было видеть лицо этой большой личности и яркого человека со свойственной ему мягкой улыбкой, на котором, казалось, прочитывалось, что он «никогда не суетился и не добивался никаких званий, кроме одного звания, которого добивался настойчиво - звания студента Петроградского университета». Думаем, что молодым, идущим в науку, обязательно нужно рекомендовать ознакомиться с биографией Василия Ивановича Абаева, записанной со слов самого ученого, чтобы знать, что «этика, красота, корректность отношений, красота речи и труда важнее всего в наше время» $[7,92]$.

Как-то Абаев признался Борису Александровичу в том, что хотел стать философом, но, ознакомившись с книгой В. Миллера «Осетинские этюды», «загорелся желанием продолжить ту работу, которую проделал Миллер, а именно осветить историю осетинского народа в свете истории языка» $[7,25]$.

Закончив блестяще Тифлисскую шестую мужскую классическую гимназию, Васо вернулся в родное село и работал учителем в школе, гордясь тем, что дал образование многим юным горцам [7, 26]. Мечту об университете он смог осуществить лишь осенью 1921 года: Васо Абаев в составе группы молодых людей 
отправляется на учебу в Петроград.

На всю жизнь Васо сохранил добрую память о Марке Авсарагове, постоянном представителе Горской республики в Москве, взявшем ребят в спецвагон: во время гражданской войны движение поездов по стране почти полностью прекратилось $[7,26]$.

Калоев высоко ценил работы Абаева, зная, что они основаны на собственном полевом материале: каждый год в свой отпуск он колесил с супругой по Кавказу в его поисках. Неплохо было бы молодым ученым поучиться у него тщательному и бережному обращению с собранным материалом, приемам самостоятельного исследования, сосредоточенности и требовательности к самому себе.

Борис Александрович пишет, что данные осетинского языка стали для Абаева важнейшим источником в решении вопросов этногенеза и этнической истории: «Элементы языка отражают элементы объективной действительности $<\ldots .>$ его (языка) показания приобретают значение исторических документов, которые, если суметь их читать, могут многое рассказать о прошлых судьбах того народа, которому этот язык принадлежит» [5, 316].

Особо впечатлило Калоева выдвинутое Абаевым доказательство участия в формировании осетинской народности и ее культуры местной кавказской среды субстрата.

Этнолог отмечает, что разрабатываемая с 20-х гг. XX в. теория субстрата находит подтверждение в этнографии осетин фактами, свидетельствующими о связях материальной и духовной культуры осетин с древнекавказским миром $[4,54]$. К примеру, наличие аланского субстрата в балкарском этническом сообществе было выявлено Абаевым еще в двадцатых годах прошлого века.

По его мнению, об этом свидетельствуют наличествующие в балкаро-ка- рачаевском языке более 200 осетинских слов, среди них есть и такие, которые в самом осетинском языке уже мало или вовсе не употребляются $[4,59]$. По Абаеву, «в действительности баксанский говор насыщен «осетизмами» не меньше других говоров и, что особенно показательно, в нем встречаются такие осетинские элементы, которых нет в более близких к Осетии говорах - чегемском и верхнебалкарском [4, 59]. Ученый заключает, что осетинские элементы в балкаро-карачаевском - «не результат новейшего заимствования из современной Осетии, а наследие старого алано-тюркского смешения, происходившего на территории всех ущелий от Терека до верховий Кубани» $[4,59]$.

В 1955 г. в Ленинграде прошла крупная научная дискуссия по докладу. Абаева об этническом субстрате, основные концепции которого приняли и лингвисты, и археологии, и этнографы и антропологи. Вызвало бурное обсуждение положение о том, что «этнический субстрат оставляет свой след не только в языке, но также и нередко в еще степени - в фольклоре, этнографии, в материальной культуре, наконец, в физическом облике народа» $[5,317]$. Калоев не раз писал о том, что научные сессии по этногенезу балкарцев и карачаевцев (1959г., г. Нальчик) и осетин (1966 г., г. Орджоникидзе) явились самым ярким подтверждением верности проблемы субстрата и его отличительных особенностей. По данным Абаева, Миллера, Дюмезиля, основанным на осетинском языке, фольклора, этнографии, несмотря на наличие сильного местного субстрата, все-таки в этногенезе осетин преобладает иранский субстрат, а в целом вклад кавказского субстрата и иранского компонента в этногенез осетин равнозначен [5, 318].

Как значительный вклад в проблему решения этногенеза осетин воспринял Б. А. Калоев теорию ареальной лингви- 
стики В. И. Абаева, занимающейся «изучением тех сходных явлений изоглоссов, которые возникают между языками определенного ареала в результате длительного соседства и контактного развития». По мнению Бориса Александровича, «блестящее применение» этой теории в монографии «Скифо-европейские изоглоссы на стыке Востока и Запада» (1965 г.) с помощью сравнительного анализа данных языка, фольклора и этнографии подтвердило скифо-сарматские контакты с германскими племенами, римлянами, прибалтами и славянскими народами [5, 319]. Результат анализа ареальных контактов скифо-сарматов и алан с народами Восточной Европы является, по мнению Калоева, неоценимым источником для этнической истории осетин.

Калоев детально анализирует изыскания Абаева по скифскому языку, выявлению скифо-сарматских черт в материальной культуре, фольклоре, мифологии и религии осетин, считая составленную великим ученым грамматику скифского языка на основе эпиграфических греческих надписей из Северного Причерноморья «научным подвигом» $[5,320]$.

Калоев вел дневниковые записи, куда по памяти заносил высказывания Василия Ивановича Абаева по разным вопросам науки.

Тезисно оформленные мысли Абаева свидетельствуют о разносторонней тематике их научных бесед. К примеру, в разговоре касались почти всех направлений науки: многие институты первобытной общины зависят от экономической ситуации в каждом конкретном случае; гостеприимство свидетельствует об уровне жизни народа; составляя историю осетин, необходимо отмечать особенность каждого села и ущелья; представило бы интерес этнографическое исследование на основе данных, содержащихся в осетинских героических песнях; отсутствие письменности можно объяснить занято- стью алан военными походами, службой у правителей разных государств; в то время, как мировая наука интересуется единственным сохранившимся древним иранским языком, языком скифо-сармато-алан, большинство осетин не знает родного языка, мотивируя тем, что «осетинский язык нужен только до Эльхотова», что способствовало его исчезновению, поэтому члены семьи должны разговаривать между собой только на родном языке, и на стене комнаты у каждой семьи должен висеть плакат с надписью «здесь говорят только по-осетински» [7, $34-36]$.

По совету Бориса Александровича, для того, чтобы глубже понять Абаева, ученого и человека, мы решили ознакомиться с дневником-приложением.

В июне 1973 г. в г. Орджоникидзе проходила сессия по кавказскому языкознанию в честь В.И. Абаева в знак благодарности за его заслуги в области общего языкознания и иранистики под руководством акад. А.Н. Чикобава. Вернувшись в Москву, Василий Иванович, за ужином рассматривая книгу Калоева, с сожалением проговорил, что если бы «Материальная культура и прикладное искусство осетин» вышла вовремя, то он непременно украсил ее рисунками уже вышедшие два тома «Историко-этимологического словаря осетинского языка» $[7,91]$.

В ноябре того же года Абаев и его супруга, Ксения Григорьевна Цхурбаева (поженились они в марте 1963 г.), устроили в Доме композиторов прием в честь группы народных певцов из Северной Осетии. На приеме звучали старинные осетинские песни. Пел и Василий Иванович, песню слышал от своего дяди по материнской линии; голос у него был приятного тембра, теплый и глубокий.

Привлекают читателя страницы, характеризующие 76-летнего Абаева: «Васо такой же подтянутый, шустрый, обладал прекрасной памятью и большой работо- 
способностью. Сильно прихрамывая, то и дело вытаскивал с полок книги, присланные ему незадолго до моего прихода из Венгрии и Англии, рассказывал о них и о встречах с недавно побывавшими у него иностранными гостями» [5, 93-94]. И в 78 лет у Василия Ивановича «ясный ум и превосходная память, у него живой вид, он худощав и очень подвижен», и в 92 года он такой же бодрый, живой, в полном здравии, без всяких отклонений в памяти [7, 95, 104]. Всех, кто близко знал Абаева, поражала его неистовая работоспособность: в 1979 г. обострилась старая болезнь, и его положили в больницу. Ученый, прикованный к постели, продолжал, не переставая, работать; его интересовало все: памятники Восточной Алании, расположенные к востоку от Северной Осетии; венгерские аланы, которые во времена нашествия татаро-монголов на Аланию ушли вместе с куманами в Венгрию и, по свидетельству английского автора, сохранили родной язык еще в XVII в.; моздокские осетины и Блашка Гуржибеков, у которого, по мнению Василия Ивановича, «богатый сочный язык, и в чистоте сохранил дигорское наречие» [7, 98].

Калоев пишет, что Абаев интересовался даже малейшими событиями в жизни Осетии, радовался ее успехам в различ- ных областях экономики и культуры и огорчался неудачам, внимательно следил за выступлениями осетинских борцов и отдельных спортсменов, за матчами футбольной команды. Он запомнил, что из осетинских писателей В.И. Абаев высоко ценил Сека Гадиева, считал слабыми переводы стихотворений Коста на русский язык, а из памятников поэту самым удачным - находящийся в Цхинвали, и пр. [7, 99]

Не только ученые, но и люди, далекие от науки, тянулись к Василию Ивановичу, им хотелось пожать ему руку, взглянуть на великого ученого; в 94 года он по-прежнему очень дорожил временем, писал, читал, вел занятия с аспирантами и научными сотрудниками, изучавшими древнеперсидский и осетинский языки.

В заключение хотелось бы привести в назидание молодым исследователям слова Василия Ивановича Абаева, зафиксированные Б.А. Калоевым, воспринимающиеся нами как завет выдающегося ученого: «Я всю жизнь упорно трудился и сейчас не могу жить, не работая, труд для меня жизненная необходимость. Обладая этим достоинством, я в какой-то мере смог выполнить поставленные перед собой изели» $[7,110]$.

1. Трубачев О.Н. Абаев Василий Иванович: Библиографический указатель литературы. Владикавказ, 1995.

2. Калоев Б.А. Записки кавказоведа. Владикавказ, 2002.

3. Калоев Б.А. Осетины: Историко-этнографическое исследование. 3-е изд. М., 2004.

4. Калоев Б.А. Ковалевский М.М. и его исследования горских народов Кавказа. М., 1979.

5. Калоев Б.А. Осетинские историко-этнографические этюды. М., 1999.

6. Калоев Б.А. Венгерские аланы (ясы). Историко-этнографический очерк. М., 1996.

7. Калоев Б.А. Василий Иванович Абаев и вопросы этнографии в его трудах. М., 2001 . 